\title{
Using marine mammal habitat modelling to identify priority conservation zones within a marine protected area
}

\author{
Helen Bailey ${ }^{1,2, *}$, Paul M. Thompson ${ }^{1}$ \\ ${ }^{1}$ University of Aberdeen, School of Biological Sciences, Lighthouse Field Station, Cromarty, Ross-shire IV11 8YJ, UK \\ ${ }^{2}$ Present address: NOAA/NMFS, Southwest Fisheries Science Center, Environmental Research Division, \\ 1352 Lighthouse Avenue, Pacific Grove, California 93950, USA
}

\begin{abstract}
One common approach to marine conservation is the designation of marine protected areas (MPAs). Marine mammals have been proposed as a target species for such areas due to their role as indicators of ecosystem processes. In NE Scotland, a large multiple-use MPA has been designated to protect bottlenose dolphins Tursiops truncatus. We used broad-scale surveys throughout this MPA to model habitat preferences of different marine mammals. We aimed to investigate the degree of overlap between distributions of different species, the environmental factors influencing their distributions, and the effect of spatial scale on the significance of different environmental predictors. Bottlenose dolphins had a primarily coastal distribution with localised areas of intense use, in contrast to harbour porpoises Phocoena phocoena, harbour seals Phoca vitulina and grey seals Halichoerus grypus, which were widely dispersed throughout the MPA. At larger scales $(4 \times 4 \mathrm{~km}$ grid cells), seal distribution was significantly related to depth, seabed slope, distance to shore and mean sea surface salinity, whereas at the smallest scale $(1 \times 1 \mathrm{~km}$ grid cells), sediment type was also important. This study demonstrated the hierarchical pattern of distributions, with areas of high relative density occurring within a broader protected area that the animals were known to regularly frequent. Habitat preference models therefore provide a valuable tool for determining which areas should be given highest conservation priority and for identifying key locations for further research on interactions between these species and anthropogenic stressors.
\end{abstract}

KEY WORDS: Special area of conservation · Generalized linear models $\cdot$ Cetaceans $\cdot$ Bottlenose dolphin $\cdot$ Harbour porpoise $\cdot$ Seals $\cdot$ Distribution

\section{INTRODUCTION}

Marine conservation is frequently based on the establishment of reserves, providing protection to target species of concern (Agardy 1994). Marine mammals are potential indicator species, such that their protection should also ensure the health of other key components of the marine ecosystem (Hooker \& Gerber 2004). In response to such suggestions, habitat distribution models have been developed to define the boundaries of marine protected areas (MPAs; Cañadas et al. 2005). Distribution patterns often exhibit a hierarchical structure, and these models can therefore provide a powerful tool for assessing areas of high relative density within MPAs, and for determining what factors influence distribution (Redfern et al. 2006). In turn, the identification of these key areas provides a focus for conservation action and appropriate management in different zones within these MPAs.

In European waters, the 1992 EU Habitats and Species Directive (92/43/EEC) has been a major driving force for the development of new MPAs (Baxter 2001), and several marine 'Special Areas of Conservation' (SACs) have been designated to protect marine mammals (Ingram \& Rogan 2002, Wilson et al. 2004). The wide-ranging behaviour of these species has led to 
large multiple-use MPAs, but it is recognised that varying levels of management need to be applied in different zones within such MPAs (Day 2002). However, uncertainty over the factors influencing finescale distribution of protected species can constrain efforts to identify where management should be focused. Similarly, MPAs established under the Habitats Directive contain several species of conservation interest, but the fine-scale distribution of different species within these protected areas is often poorly known. As a result, it can be difficult to assess to what extent management practices support Hooker \& Gerber's (2004) suggestion that protection of one key species necessarily protects other components of the ecosystem.

In NE Scotland, a large portion of the Moray Firth has been designated as an SAC, making this one of the largest MPAs in Europe. Designated primarily to protect a resident population of bottlenose dolphins Tursiops truncatus, the area is also important for marine mammals such as harbour porpoises Phocoena phocoena, minke whales Balaenoptera acutorostrata, and grey Halichoerus grypus and harbour seals Phoca vitulina. While the importance of this area for bottlenose dolphins is well known, previous studies (e.g. Wilson et al. 1997) have focused on inshore areas that represent only about $10 \%$ of the $1512 \mathrm{~km}^{2}$ MPA (Hoyt 2005). In contrast, little is known about the distribution of this species or other cetaceans within the remainder of the MPA (Northridge et al. 1995, Hammond et al. 2002, Hastie et al. 2003). When species require similar resources, temporal or spatial segregation may occur to reduce competition (Roughgarden 1976). Such habitat partitioning has been observed in many marine species (e.g. Gowans \& Whitehead 1995). Alternatively, species may be able to coexist as a result of dietary differences or by using the area for different functions, so they do not exert a strong competitive pressure on each other (Bearzi 2005). Information on the at-sea distribution of instrumented grey and harbour seals (Thompson et al. 1996, Tollit et al. 1998) suggests that their foraging activity is focused in areas that are farther offshore than those in which dolphins are most frequently sighted (e.g. Wilson et al. 1997, Hastie et al. 2003). However, methodological differences currently make it difficult to compare the at-sea distribution of these different marine mammal species within this MPA.

We aimed to develop habitat preference models to predict high-density areas for marine mammals within this MPA as a tool for focusing management efforts. The distribution of marine mammal species was determined using combined visual and passive acoustic techniques. These were analysed in relation to environmental variables, and the effect of spatial scale on the significance of these predictors was examined.

\section{MATERIALS AND METHODS}

Data collection. Combined boat-based visual and passive acoustic line transect surveys were conducted in the Moray Firth MPA during August to October 2004 and April to July 2005. Surveys were performed from an $8.5 \mathrm{~m}$ Newhaven Sea Warrior motor vessel at an average speed of 7 knots. The pre-defined survey route was designed by overlaying a $4 \times 4 \mathrm{~km}$ grid and including survey effort from at least 2 separate survey days within each square. Data on survey effort were collected using a GPS (Lowrance LMS 330C) and stored in a Microsoft Access database using IFAW Logger 2000 software (www.ifaw.org). Environmental data on sea state, wind direction and visibility were inputted manually every hour. Surveys were generally carried out in good visibility $(>5 \mathrm{~km})$ with no precipitation and in sea states less than Beaufort 4. A conductivity, temperature and depth instrument (StarOddi DST-CTD) was towed behind the boat at 1 to $2 \mathrm{~m}$ depth to make simultaneous sea surface temperature and salinity measurements during surveys.

Visual marine mammal surveys were conducted from the top of the wheelhouse, approximately $3.5 \mathrm{~m}$ above sea level. Observers scanned the area directly ahead to $90^{\circ}$ off either side of the boat, by eye and with $7 \times 50$ binoculars. When marine mammals were sighted, information on species, group size, distance and bearing (using a reticule and compass within the binoculars) were recorded in Logger. This automatically stored the time and GPS location of the boat during the sighting. The observer was changed every 30 to 60 min to avoid fatigue. The boat did not deviate from the pre-defined route when animals were encountered.

Passive acoustic equipment consisted of a towed hydrophone array and an automated detection system. The hydrophone array was towed $150 \mathrm{~m}$ behind the vessel at a depth of 8 to $9 \mathrm{~m}$. Th array consisted of 2 pairs of stereo hydrophone elements, approximately $3 \mathrm{~m}$ apart (Leaper et al. 2000). One pair of hydrophones had a flat response to frequencies up to $15 \mathrm{kHz}$, enabling the detection of dolphin whistles and the lower frequency components of broad-band echolocation clicks (Hastie et al. 2003). Signals were filtered to remove background boat noise with a $1.6 \mathrm{kHz}$ high pass filter, amplified by $30 \mathrm{~dB}$ in reference to (re) $1 \mu \mathrm{Pa}$, and digitised using a sound card (Roland UA-100G). Software (IFAW Whistle v3.01.0002) automatically detected dolphin whistles in real time (Lewis et al. 2000). Recordings were also made onto audio tape (Marantz CP430 cassette recorder) so automatic detections could later be confirmed.

The second pair of hydrophones detected high frequency harbour porpoise echolocation clicks. Harbour porpoises produce narrow band echolocation clicks, 
with their dominant energy at 115 to $145 \mathrm{kHz}$ (Chappell et al. 1996), allowing discrimination from other sources producing broad-band sounds at this frequency (Gillespie \& Chappell 2002). Hydrophone inputs were connected to signal processing units, which had 3 separate band-pass filters centred at 50, 75 and $125 \mathrm{kHz}$ (Seiche). The highest of these encompassed the frequency band at which harbour porpoises vocalise. Porpoise clicks were defined as requiring a minimum amplitude in the $125 \mathrm{kHz}$ band of $105 \mathrm{~dB}$ re $1 \mu \mathrm{Pa}$, and a minimum difference of $30 \mathrm{~dB}$ re $1 \mu \mathrm{Pa}$ between the amplitude at $125 \mathrm{kHz}$ and that in the other 2 bands, 50 and $75 \mathrm{kHz}$ (IFAW Porpoise Detector Version 3.00.0007). Bearings were calculated based on the difference in the time of arrival of a signal to each hydrophone (Gillespie \& Chappell 2002). As the boat progressed along the transect, a series of sequential bearings produced a track showing the movement of the porpoise relative to the boat, aiding confirmation of the detection. Visual observers were not notified of any acoustic detections, so the 2 detection methods can be considered independent. On occasions when both an acoustic detection and visual sighting occurred, this information was recorded in the Logger database, but was considered only a single encounter in the analysis.

Data analysis. The locations of survey effort and marine mammal sightings were plotted in the GIS software ArcView 3.3 (ESRI). Using generalized linear models (GLMs; Dobson 2002), we investigated the distribution of each marine mammal species in relation to environmental variables using the software $\mathrm{R}$ version 1.8.1 (R Development Core Team 2003). These variables included depth, seabed slope, distance to the shore, mean sea surface salinity and seabed sediment type. Data on bathymetry and seabed sediment types, derived from data in $25 \times 25 \mathrm{~m}$ grid cells, were provided by Scottish Natural Heritage for the areas within the $20 \mathrm{~m}$ contour and at the mouths of the inner firths. Data were obtained for the remaining area from the British Geological Survey at a scale of 1:250 000 (DIGBATH 250 Licence 2004/105 DB and BGS digital data Licence 2004/104 (C NERC). The seabed sediment classifications are based on the gravel percentage and sand to mud ratio as described by Folk (1954). Seabed slope was calculated using the 'derive slope' function and the distance to shore using the 'find distance' function in ArcView 3.3.

The study area was divided into $4 \times 4 \mathrm{~km}$ grid squares, and a mean value for each environmental variable was assigned to each cell (Fig. 1). Seabed sediment type was given as a categorical variable, classified as rock and gravel (the reference level), sand, muddy sand and sandy mud. The remaining explanatory variables were treated as continuous covariates. Since for seals only visual observations were made, mean sea state within each grid cell was also included as a covariate, as this can affect the probability of detection. Depths were classed in $5 \mathrm{~m}$ intervals and slope at $0.05^{\circ}$ intervals to reduce differences resulting from the transition between data sources. A tolerance statistic, $1-r_{X}^{2}$, where $r_{x}^{2}$ is the variance in each independent variable $x$ explained by the other independent variables, was calculated to test for collinearity (Gregr \& Trites 2001). A low tolerance indicates that the variable is correlated with 1 or more of the other explanatory variables, with a value below 0.1 being of concern (Quinn \& Keough 2002). The response variable was the number of sightings of a given species within each grid cell. Models were fitted assuming a Poisson or quasi-Poisson error distribution, with a log link function. Survey effort was given as the distance searched within each grid cell, and the log of this was included as an offset variable. Visual inspection of univariate scatterplots was used to conduct a preliminary assessment of potential predictors and whether polynomial terms should be included in the model. The best model was selected through backward stepwise selection using the Akaike Information Criterion (AIC). This was repeated for $1 \times 1 \mathrm{~km}$ and $2 \times 2 \mathrm{~km}$ grids to investigate the effect of different grain sizes on the importance of the environmental predictors while keeping the extent of the study area constant (Wiens 1989). Slope was categorised at $0.1^{\circ}$ intervals for these smaller grid sizes.

\section{RESULTS}

In total, $1915 \mathrm{~km}$ were surveyed during 2004 and 2005 within the bottlenose dolphin MPA (Fig. 2). The study area included the area west of the line between Tarbat Ness (57 $52^{\prime} \mathrm{N}, 3^{\circ} 47^{\prime} \mathrm{W}$ ) and Burghead $\left(57^{\circ} 43^{\prime} \mathrm{N}, 3^{\circ} 30^{\prime} \mathrm{W}\right)$ during 2004 and throughout the MPA in 2005. Three cetacean and 2 pinniped species were encountered (Table 1). There were 63 bottlenose dolphin encounters, of which 7 were detected only acoustically $(11 \%)$. The mean $( \pm \mathrm{SE})$ group size during visual encounters was $3.17( \pm 0.39)$ individuals. Harbour porpoises were the most frequently encountered species. Unfortunately, the acoustic porpoise detector failed during 2004. In 2005, 33 acoustic harbour porpoise detections were made with no corresponding visual sighting (38\% of total encounters). During visual sightings, harbour porpoises were seen in small groups of 1 or 2 animals (mean $1.47 \pm 0.08$ individuals). Visual and acoustic detections showed a similar spatial distribution and were therefore combined for all further analyses to maximise the sample size. Minke whales were sighted on 10 occasions, all of them single animals. These occurred both within the inner parts of the 

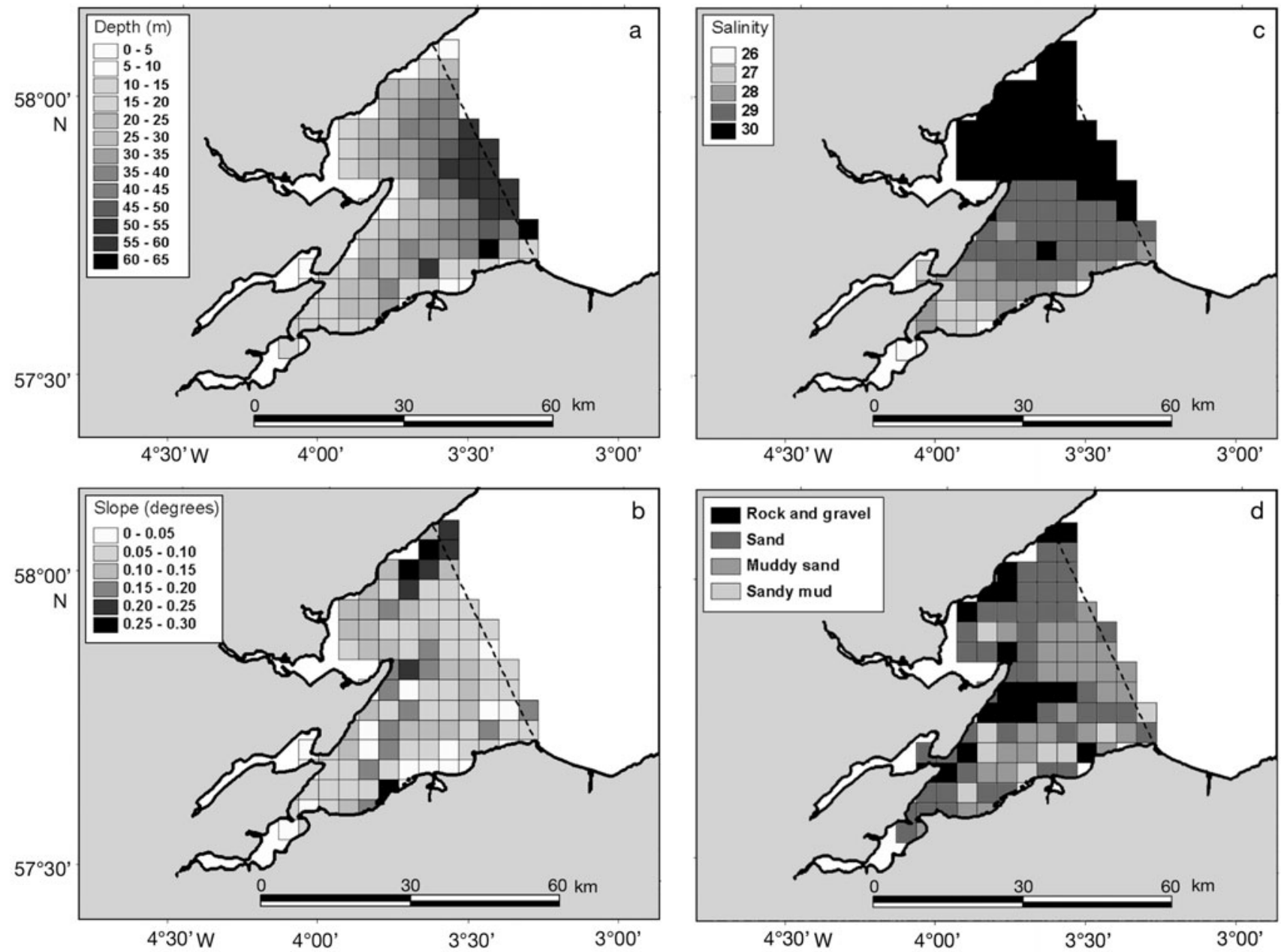

Fig. 1. (a) Mean depth, (b) seabed slope, (c) sea surface salinity and (d) seabed sediment type in $4 \times 4 \mathrm{~km}$ grid cells within the study area

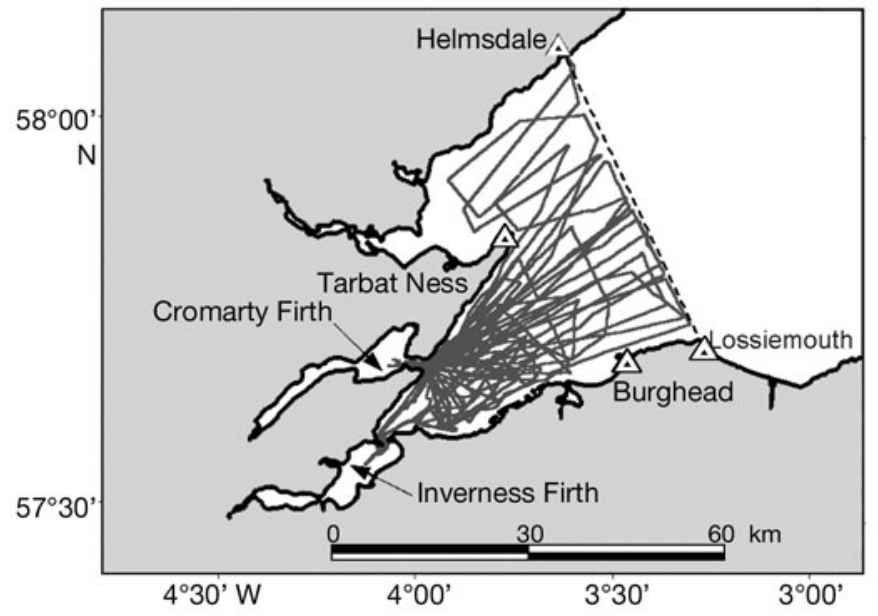

Fig. 2. Survey transects conducted during 2004 and 2005 within the bottlenose dolphin marine protected area (MPA) in the Moray Firth (Scotland). Outer eastern boundary of the MPA shown as a black dashed line
Moray Firth and farther from shore near the outer MPA boundary (Fig. 3), but no analyses of relationships with environmental variables were made due to the small sample size.

There were also 28 sightings of grey seals and 24 of harbour seals, mainly of single animals, with a high degree of spatial overlap between species. Unidentified seal species were recorded on 17 occasions. These 3 categories were pooled together to form a seal species group to increase the sample size for the GLM analysis.

Collection of sighting data along continuous tracks results in potential spatial autocorrelation (Redfern et al. 2006). There was more than one occurrence of a species in 41 to $56 \%$ of the surveys. However, the mean distance between encounters was $>4 \mathrm{~km}$ for bottlenose dolphins, harbour porpoises and seals $(9.70$, 6.65 and $7.25 \mathrm{~km}$, respectively). There were few occasions when sightings of the same species were recorded in succession. Surveys were also conducted on 
Table 1. Survey effort and number of marine mammal encounters (visual and acoustic detections are combined for bottlenose dolphins and harbour porpoises). Encounter rates given in parentheses

\begin{tabular}{|lcccccc|}
\hline Year & $\begin{array}{c}\text { Survey } \\
\text { days }\end{array}$ & $\begin{array}{c}\text { Distance } \\
\text { surveyed } \\
(\mathrm{km})\end{array}$ & $\begin{array}{c}\text { Bottlenose } \\
\text { dolphin }\end{array}$ & $\begin{array}{l}\text { Harbour } \\
\text { porpoise }\end{array}$ & $\begin{array}{l}\text { Minke } \\
\text { whale }\end{array}$ & $\begin{array}{c}\text { Seal } \\
\text { species }\end{array}$ \\
\hline 2004 & 12 & 605 & $30(5.0)$ & $15(2.5)$ & $5(0.8)$ & $30(5.0)$ \\
2005 & 15 & 1310 & $33(2.5)$ & $73(5.6)$ & $5(0.4)$ & $39(3.0)$ \\
Total & $\mathbf{2 7}$ & $\mathbf{1 9 1 5}$ & $\mathbf{6 3}(\mathbf{3 . 3})$ & $\mathbf{8 8}(\mathbf{4 . 6 )}$ & $\mathbf{1 0}(\mathbf{0 . 5 )}$ & $\mathbf{6 9 ( 3 . 6 )}$ \\
\hline
\end{tabular}

seabed slope and distance to shore (Table 2). More encounters occurred close to shore and where the seabed gradient was less steep near the shore. The highest relative densities of bottlenose dolphins were therefore predicted to occur along the coast and within the inner parts of the Moray Firth (Fig. 4b). There was also a significant negative relationship with distance to shore for the 2 smaller grid sizes (Table 3).

$27 \mathrm{~d}$, spanning over $2 \mathrm{yr}$, and passed through most of the $4 \times 4 \mathrm{~km}$ grid cells at least twice, thus reducing the likelihood that autocorrelation may be a problem in this case. The tolerances for the explanatory variables were greater than 0.1 for every grid size, indicating that the amount of collinearity was not significant at these scales (tolerance statistic range $=0.38$ to 0.91 , 0.31 to 0.89 and 0.26 to 0.87 for the $1 \times 1,2 \times 2$ and $4 \times$ $4 \mathrm{~km}$ grid cells, respectively).

Bottlenose dolphins were distributed patchily (Fig. 4a), mainly occurring within the inner Moray Firth, but with some encounters off Tarbat Ness and near Helmsdale. In contrast, harbour porpoises were more widely dispersed, occurring throughout the MPA (Fig. 5a). Seals were also sighted throughout the area, particularly along the northern coast, off Tarbat Ness and at the entrances to the Cromarty and Inverness Firths (Fig. 6a). Most overlap occurred between bottlenose dolphins, harbour porpoises and seals at these latter 2 sites. However, the environmental variables found to be significant predictors of distribution differed between species.

The number of bottlenose dolphin encounters within each $4 \times 4 \mathrm{~km}$ grid cell was significantly related to the distance from shore and the interaction between

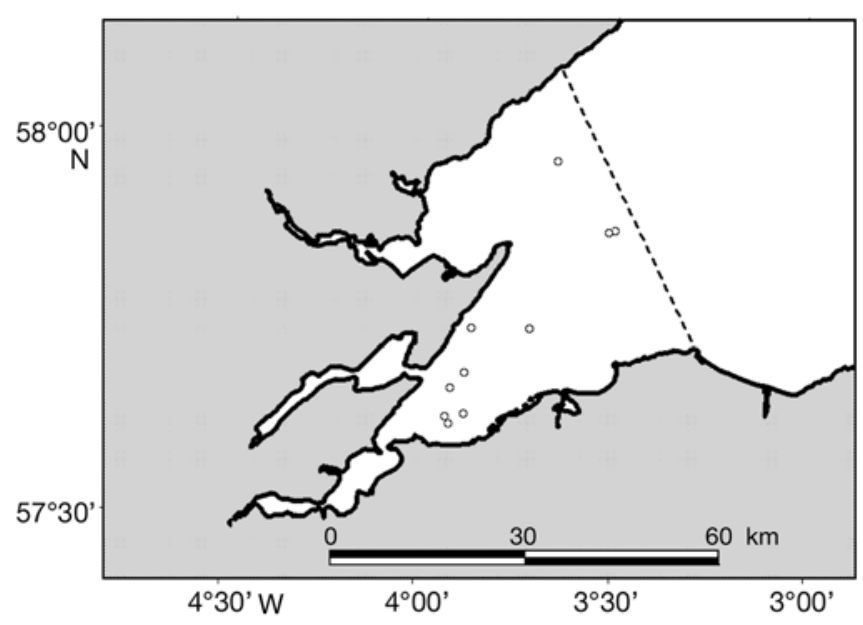

Fig. 3. Balaenoptera acutorostrata. Sightings of minke whales in the Moray Firth marine protected area (o)
The distribution of harbour porpoise encounters was not significantly related to any environmental variables in the model within a $4 \times 4 \mathrm{~km}$ grid, although many terms were retained in the final model (Table 2). The predictions from the model indicated highest relative densities occurring within the centre of the area from and also off Helmsdale (Fig. 5b). At the smaller grid

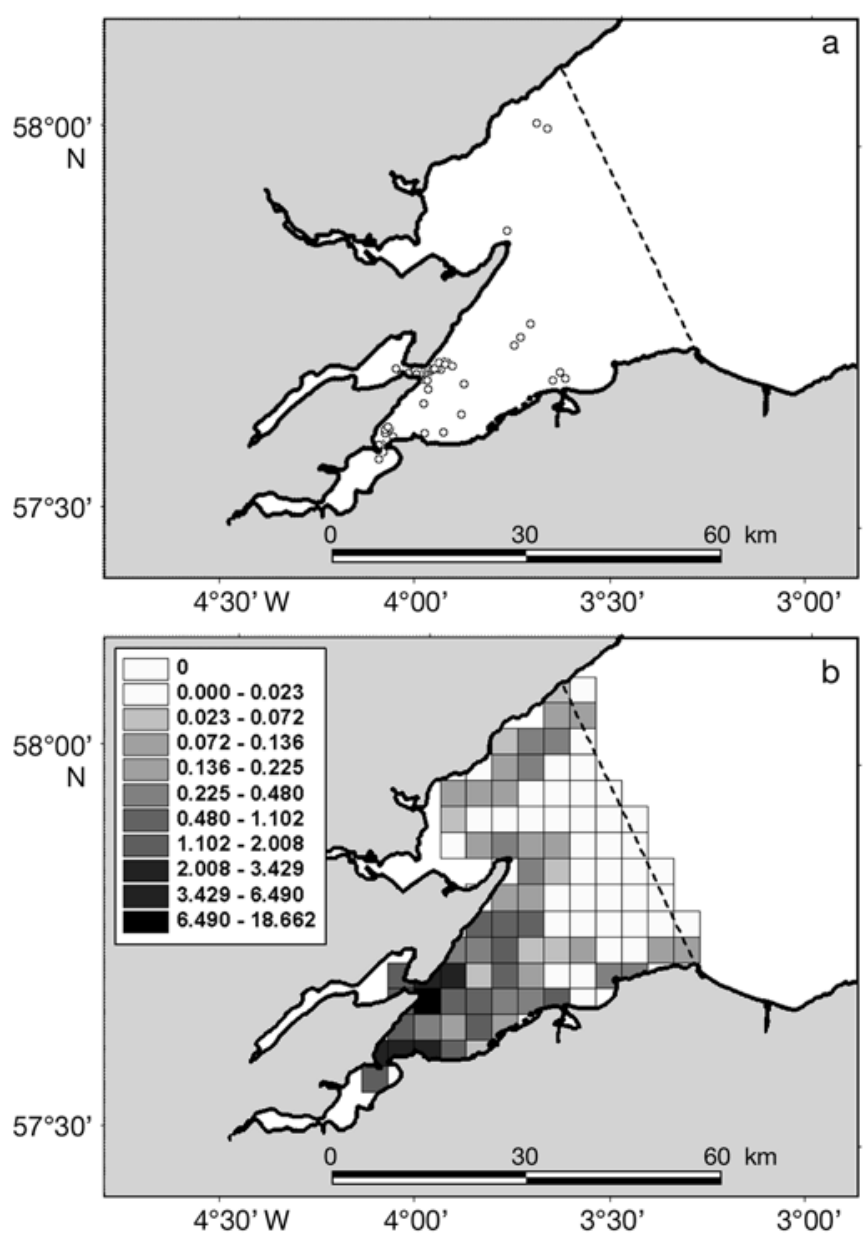

Fig. 4. Tursiops truncatus. (a) Sightings of bottlenose dolphins (०), (b) prediction of relative density of bottlenose dolphins within $4 \times 4 \mathrm{~km}$ grid cells in the marine protected area the outer MPA boundary towards the Inverness Firth 


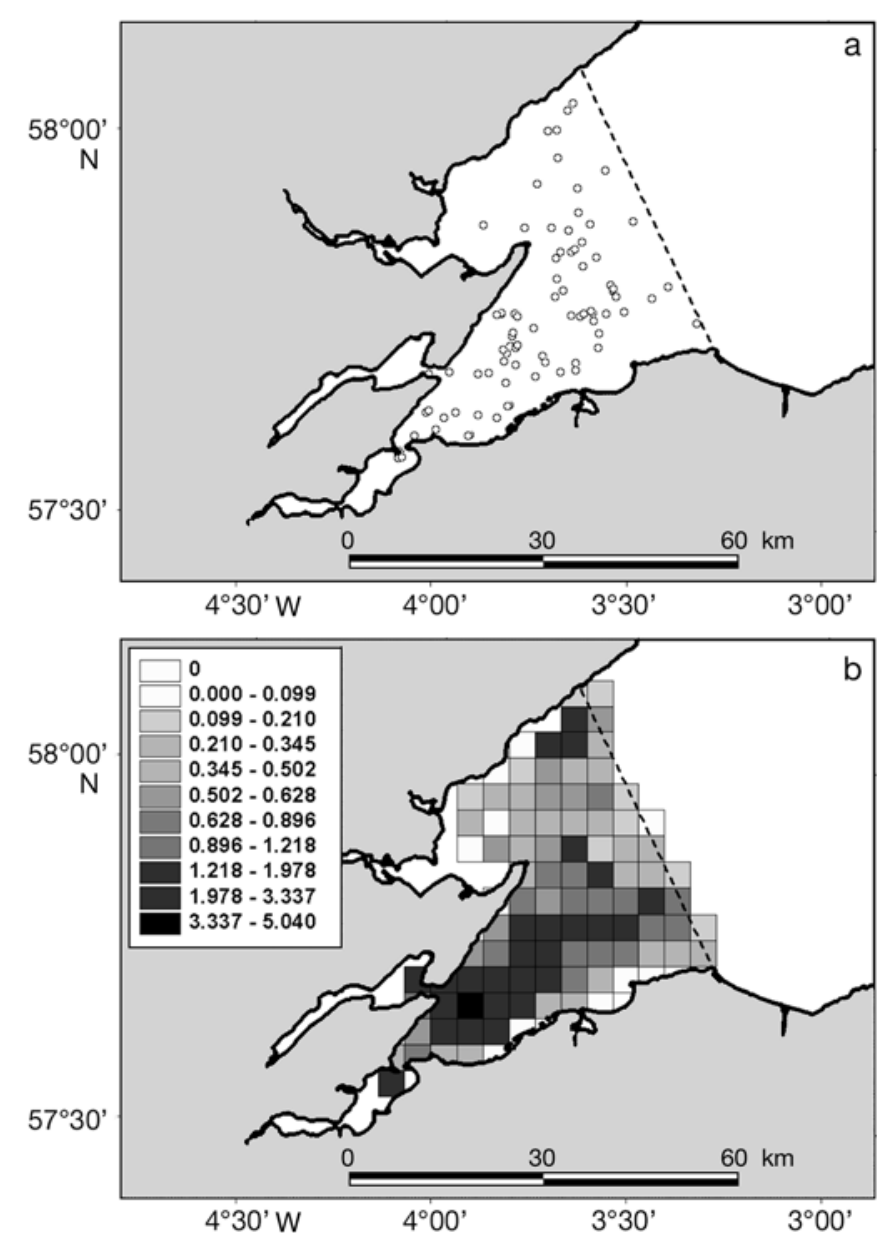

Fig. 5. Phocoena phocoena. (a) Sightings of harbour porpoises (o), (b) prediction of relative density of harbour porpoises within $4 \times 4 \mathrm{~km}$ grid cells in the marine protected area

sizes, there were significant relationships with environmental parameters (Table 3 ). Within a $2 \times 2 \mathrm{~km}$ grid, distance to shore was a significant predictor, with more porpoises occurring at 5 to $15 \mathrm{~km}$ from land. More porpoises were also encountered over sandy seabed sediments than over rock and gravel. In contrast, within a $1 \times 1 \mathrm{~km}$ grid, depth was a significant variable, whereas distance to shore was not. More porpoises occurred where it was deeper, peaking at 10 to $35 \mathrm{~m}$ depth. Depth and distance to shore were significantly positively correlated. The determination of which of these variables acted as a better predictor therefore depended on the scale at which it was examined.

The number of seal sightings within each $4 \times 4 \mathrm{~km}$ grid cell was significantly related to depth, seabed slope, distance to shore and sea surface salinity (Table 2). Sea state was not a significant predictor variable and did not affect the significance of any of the other covariates. It was therefore not included in the final model. The relationship with depth was bimodal,
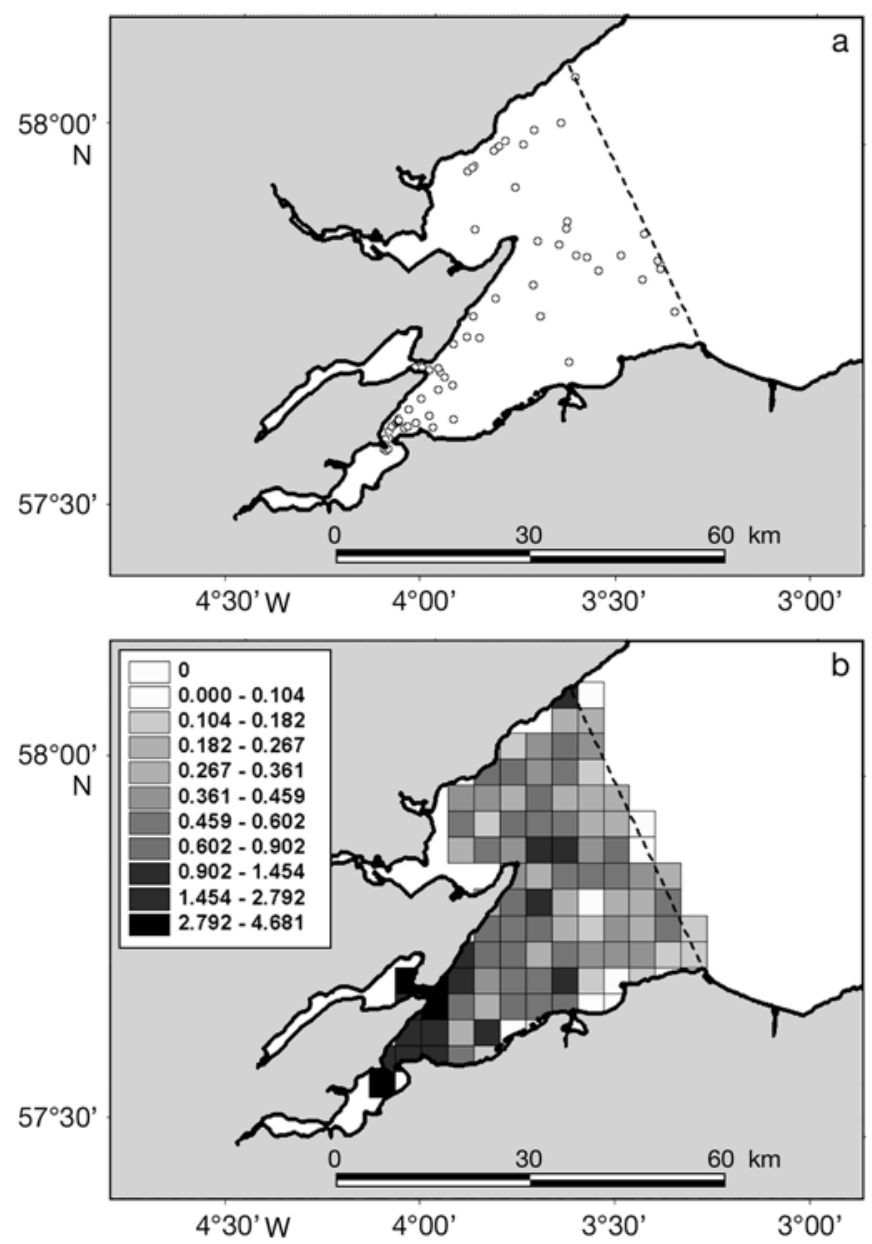

Fig. 6. Phoca vitulina and Halichoerus grypus. (a) Sightings of seals (o), (b) prediction of relative density of seals within $4 \times$ $4 \mathrm{~km}$ grid cells in the marine protected area

peaking in shallow areas 0 to $20 \mathrm{~m}$ deep and in deeper areas of 40 to $55 \mathrm{~m}$ depth. A similar relationship was found with salinity, with sightings peaking at low (26 to 28 ) and higher (30) sea surface salinities. More seals also occurred close to shore and where the seabed gradient was less steep. The highest relative densities of seals were predicted to occur at the entrances to the Inverness and Cromarty Firths and off Tarbat Ness (Fig. 6b). At the smallest grid size, sightings were significantly lower over sandy mud (the finest sediment category) than over rock and gravel (the coarsest sediment type; Table 3 ).

\section{DISCUSSION}

This MPA was originally designated to protect bottlenose dolphins. Early studies revealed that sightings of this species occurred predominantly within 3 regions in the inner Moray Firth, but these were based 
Table 2. Coefficient estimates from the generalized linear models (GLMs) analysis for bottlenose dolphins, harbour porpoises and seals within a $4 \times 4 \mathrm{~km}$ grid. Sediment type was treated as a categorical variable with rock and gravel as the reference level. Parameters with $\mathrm{p}<0.05$ are shown in bold. Interaction terms are indicated by a colon, and variables not included in the final model by a dash

\begin{tabular}{|c|c|c|c|c|c|c|}
\hline \multirow{2}{*}{$\begin{array}{l}\text { Environmental } \\
\text { factor }\end{array}$} & \multicolumn{2}{|c|}{ - Bottlenose dolphin -} & \multicolumn{2}{|c|}{ - Harbour porpoise } & \multirow{2}{*}{$\begin{array}{l}\text { Seals } \\
\text { Estimate (SE) }\end{array}$} & \multirow[b]{2}{*}{$\mathrm{p}$} \\
\hline & Estimate (SE) & $\mathrm{p}$ & Estimate (SE) & $\mathrm{p}$ & & \\
\hline Intercept & $1.278(7.378)$ & 0.863 & $17.830(15.090)$ & 0.241 & $351.8(114.0)$ & 0.003 \\
\hline Depth & $1.304(0.735)$ & 0.079 & $0.116(0.103)$ & 0.263 & $-0.426(0.236)$ & 0.075 \\
\hline Depth $^{2}$ & $-0.111(0.079)$ & 0.165 & - & - & $0.004(0.002)$ & 0.040 \\
\hline Slope & $-0.786(0.407)$ & 0.056 & $-13.470(7.234)$ & 0.066 & $-0.605(0.277)$ & 0.031 \\
\hline Distance & $\begin{array}{c}-0.001 \\
\left(4.195 \times 10^{-4}\right)\end{array}$ & 0.004 & $0.004(0.004)$ & 0.301 & $\begin{array}{l}-4.187 \times 10^{-4} \\
\left(1.543 \times 10^{-4}\right)\end{array}$ & 0.008 \\
\hline Salinity & $-0.175(0.266)$ & 0.513 & $-0.792(0.530)$ & 0.138 & $-25.460(8.108)$ & 0.002 \\
\hline Salinity $^{2}$ & - & - & - & - & $0.459(0.144)$ & 0.002 \\
\hline \multicolumn{7}{|l|}{ Sediment type } \\
\hline Sand & $-0.037(0.368)$ & 0.920 & $0.430(0.386)$ & 0.269 & $0.386(0.380)$ & 0.312 \\
\hline Muddy sand & $-0.353(0.790)$ & 0.656 & $-8.612 \times 10^{-4}(0.479)$ & 0.999 & $0.187(0.589)$ & 0.751 \\
\hline Sandy mud & $-1.361(1.428)$ & 0.343 & $-0.857(0.637)$ & 0.182 & $-0.641(0.784)$ & 0.416 \\
\hline \multicolumn{7}{|l|}{ Interactions } \\
\hline Slope:Distance & $\begin{array}{c}2.930 \times 10^{-4} \\
\left(1.137 \times 10^{-4}\right)\end{array}$ & 0.012 & $\begin{array}{c}8.580 \times 10^{-5} \\
\left(1.666 \times 10^{-3}\right)\end{array}$ & 0.959 & $\begin{array}{c}9.579 \times 10^{-5} \\
\left(5.249 \times 10^{-5}\right)\end{array}$ & 0.071 \\
\hline Slope:Salinity & - & - & $0.475(0.248)$ & 0.059 & - & - \\
\hline Distance:Salinity & - & - & $\begin{array}{l}-1.240 \times 10^{-4} \\
\left(1.239 \times 10^{-4}\right)\end{array}$ & 0.320 & - & - \\
\hline $\begin{array}{l}\text { Slope:Distance: } \\
\text { Salinity }\end{array}$ & - & - & $\begin{array}{c}-4.578 \times 10^{-6} \\
\left(5.675 \times 10^{-5}\right)\end{array}$ & 0.936 & - & - \\
\hline$\%$ deviance explained & \multicolumn{2}{|c|}{62.5} & \multicolumn{2}{|l|}{26.9} & \multicolumn{2}{|l|}{27.6} \\
\hline
\end{tabular}

Table 3. Variables from the final selected generalized linear models (GLMs) that were significant at the $5 \%$ level for the 3 grid sizes, where + is positive and - is a negative relationship

\begin{tabular}{|c|c|c|c|}
\hline Species & $1 \times 1 \mathrm{~km}$ & $2 \times 2 \mathrm{~km}$ & $4 \times 4 \mathrm{~km}$ \\
\hline $\begin{array}{l}\text { Bottlenose } \\
\text { dolphin }\end{array}$ & Distance (-) & $\begin{array}{c}\text { Distance }(-) \\
\text { Slope }(+)\end{array}$ & $\begin{array}{c}\text { Distance (-) } \\
\text { Slope:Distance (+) }\end{array}$ \\
\hline $\begin{array}{l}\text { Harbour } \\
\text { porpoise }\end{array}$ & $\begin{array}{l}\text { Depth }(+) \\
\operatorname{Depth}^{2}(-) \\
\text { Slope }(-)\end{array}$ & $\begin{array}{c}\text { Distance (+) } \\
\text { Distance (+) } \\
\text { Sediment (sand) }(+) \\
\text { Slope:Distance }(-)\end{array}$ & \\
\hline $\begin{array}{r}\text { Seal species } \\
\text { Sec }\end{array}$ & $\begin{array}{c}\text { Depth (-) } \\
\text { Slope }^{2}(-) \\
\text { Distance (-) } \\
\text { diment (sandy mud) }(-) \\
\text { Depth:Slope (+) } \\
\text { Distance:Salinity (+) }\end{array}$ & $\begin{array}{c}\text { Depth (-) } \\
\text { Depth:Slope (+) } \\
\text { Slope:Distance (-) } \\
\text { Slope:Distance: } \\
\text { Salinity (+) }\end{array}$ & $\begin{array}{c}\text { Depth }^{2}(+) \\
\text { Slope (-) } \\
\text { Distance (-) } \\
\text { Salinity (-) } \\
\text { Salinity }^{2}(+)\end{array}$ \\
\hline
\end{tabular}

the areas of highest relative density occurred close to the shore. Given that most human activities occur in this part of the MPA, these inshore areas may be particularly sensitive and require a higher level of conservation effort to protect bottlenose dolphins.

In contrast, harbour porpoise distribution was more dispersed, occurring throughout the MPA. Although porpoises were detected close to land, high relative densities were also recorded farther offshore. Since more of the offshore areas were surveyed in 2005, this may explain the higher encounter rate in this year than in 2004 (Table 1). On the only occasion where dolphin and porpoise sightings were made within 1 $\mathrm{km}$ of each other, they were temporally separated by nearly $10 \mathrm{~h}$. Bottlenose dolphins are known to violently attack harbour porpoises (Ross \& Wilson 1996, Jepson \& Baker 1998), and fine-scale segregation has been found to occur in the outer Moray Firth (Thompson et al. 2004). Management of bottlenose dolphin habitats should therefore also provide some protection to harbour porpoises, but only within part of the area used by porpoises. on inshore surveys that did not encompass the entire MPA (Wilson et al. 1997). Subsequent wider-scale surveys did not detect any bottlenose dolphins in offshore areas outside the MPA, but low sample sizes precluded further investigation of habitat preferences at this broad scale (Hastie et al. 2003). Our study, which involved much greater effort in offshore parts of the MPA, confirms the primarily coastal distribution of this population. Habitat preference models predicted that 
Unlike cetaceans, seals are central-place foragers (Härkönen 1987), with grey seals tending to travel farther from haul-out sites than harbour seals (Thompson et al. 1996, McConnell et al. 1999). The bimodal relationship with depth and sea surface salinity may represent species-specific preferences or differences in environmental characteristics within haul-out and foraging areas (Matthiopoulos et al. 2004). The areas predicted to have high relative densities matched well with earlier telemetric studies (Thompson et al. 1996, Tollit et al. 1998), indicating that the use of visual observations only for seals did not strongly bias the resulting distribution. The area predicted to have high relative densities off Tarbat Ness (Fig. 6) has previously been shown to be a foraging area for both harbour and grey seals (Thompson et al. 1996). Earlier telemetric studies also indicated that harbour seals mainly foraged within water 10 to $50 \mathrm{~m}$ deep and over sandy seabeds (Tollit et al. 1998). The destinations of grey seals, satellite tracked in the North Sea, were often localised areas characterised by gravel/sand sediment types (McConnell et al. 1999). In this study, seals were associated with coarser sediment types (rock/gravel/sand) only at the smallest grid size $\left(1 \mathrm{~km}^{2}\right)$, indicating that selection of these areas occurred on a localised scale. The importance of sediment type may be driven by the preferences of their prey. For example, sandeels, a known seal prey item (Hammond et al. 1994, Thompson et al. 1996, Brown \& Pierce 1998), avoid sediments with a silt/clay content of more than $10 \%$ (Wright et al. 2000).

Although only a few minke whale sightings were made, they occurred throughout the survey period, indicating they are present throughout the spring to autumn. Previously, sightings have generally occurred in June to October, indicating that they visit the Moray Firth in late summer to forage (Robinson \& Tetley 2007). An estimated 8000 minke whales occur in the North Sea and adjacent waters, with most sightings in the northern North Sea (Hammond et al. 2002). Further monitoring is required to gain a better understanding of their distribution and habitat preferences in this area.

Habitat partitioning between marine mammal species has been reported in a number of areas around the world (Findlay et al. 1992, Gowans \& Whitehead 1995, Weir et al. 2001). Although seals, harbour porpoises and minke whales occurred in more offshore areas than bottlenose dolphins, there was much overlap in their distributions. Protection of bottlenose dolphins in this MPA should therefore also aid conservation of these other marine mammal species. The habitat preference model predictions can be used to suggest locations for further research, such as areas with high relative densities beyond the regular survey route.

In analyses such as these, grid size affects the amount of effort and number of sightings within each square. At larger grid sizes, the sighting rate is higher but the environmental conditions are averaged over a larger area (Hamazaki 2002, Redfern et al. 2008). Analysis will also be constrained by the accuracy of animal positioning and the resolution of environmental data (Bradshaw et al. 2002). There appeared to be no clear progression in the significance of variables with grid size in the present study. This may indicate that they represented different domains of scale, causing sharp transitions in dominance of 1 set of factors to another (Wiens 1989). Alternatively, the lack of information on the behaviour of the groups encountered, such as whether they were travelling or foraging, or the method by which the environmental variables were categorised may have influenced the relationships. Combining environmental factors into ecoregions (Lea \& Dubroca 2003) and including temporal variability may also improve descriptions of habitat preferences.

This study demonstrated the hierarchical pattern of distributions, with localised areas of high relative density occurring within a broader area (the MPA) that the animals were known to use. The MPA provides protection not only for the species for which it was designated, i.e. the bottlenose dolphin, but also to several other marine mammal species that regularly occur within the area (Hooker \& Gerber 2004). These distribution patterns were significantly related to environmental parameters and highlight locations for further research. Habitat preference models therefore provide a biological rationale for determining which areas should be given highest conservation priority and creating management zones within those areas (Day 2002).

Acknowledgements. We are grateful to everyone who helped with the data collection, particularly T. Barton, K. Brookes, B. Cheney, E. Coates, T. Gridley, D. Lusseau, S. Pern, B. Senior and A. Virjee. Thank you to R. Foster-Smith at Envision Mapping Ltd. and Scottish Natural Heritage for providing the high resolution bathymetry and seabed sediment data and to C. Embling, J. Gordon, P. Hammond and S. Mendes for their valuable advice. The software Logger, Whistle and Porpoise Detector were developed by the International Fund for Animal Welfare to promote benign and non-invasive research. Financial support was provided by the University of Aberdeen, Whale and Dolphin Conservation Society, Talisman Energy (UK) Ltd. and the EU DOWNVInD project.

\section{LITERATURE CITED}

Agardy MT (1994) Advances in marine conservation: the role of marine protected areas. Trends Ecol Evol 9:267-270

> Baxter JM (2001) Establishing management schemes on marine Special Areas of Conservation in Scotland. Aquat Conserv: Mar Freshw Ecosyst 11:261-265

> Bearzi M (2005) Dolphin sympatric ecology. Mar Biol Res 1: 165-175

- Bradshaw CJA, Hindell MA, Michael KJ, Sumner MD (2002) The optimal spatial scale for the analysis of elephant seal 
foraging as determined by geo-location in relation to sea surface temperatures. ICES J Mar Sci 59:770-781

Brown EG, Pierce GJ (1998) Monthly variation in the diet of harbour seals in inshore waters along the southeast Shetland (UK) coastline. Mar Ecol Prog Ser 167:275-289

Cañadas A, Sagarminaga R, De Stephanis R, Urquiola E, Hammond PS (2005) Habitat preference modelling as a conservation tool: proposals for marine protected areas for cetaceans in southern Spanish waters. Aquat Conserv: Mar Freshw Ecosyst 15:495-521

Chappell OP, Leaper R, Gordon J (1996) Development and performance of an automated harbour porpoise click detector. Rep Int Whaling Comm 46:587-594

> Day J (2002) Zoning - lessons from the Great Barrier Reef Marine Park. Ocean Coast Manag 45:139-156

Dobson AJ (2002) An introduction to generalized linear models. Chapman \& Hall/CRC, Boca Raton, FL

Findlay KP, Best PB, Ross GJB, Cockcroft VG (1992) The distribution of small odontocete cetaceans off the coasts of South Africa and Namibia. S Afr J Mar Sci 12: 237-270

Folk RL (1954) The distinction between grain size and mineral composition in sedimentary-rock nomenclature. J Geol 62: 344-359

Gillespie D, Chappell O (2002) An automatic system for detecting and classifying the vocalisations of harbour porpoises. Bioacoustics 13:37-61

Gowans S, Whitehead H (1995) Distribution and habitat partitioning by small odontocetes in the Gully, a submarine canyon on the Scotian Shelf. Can J Zool 73:1599-1608

Gregr EJ, Trites AW (2001) Predictions of critical habitat for five whale species in the waters of coastal British Columbia. Can J Fish Aquat Sci 58:1265-1285

- Hamazaki T (2002) Spatiotemporal prediction models of cetacean habitats in the mid-western North Atlantic Ocean (from Cape Hatteras, North Carolina, USA to Nova Scotia, Canada). Mar Mamm Sci 18:920-939

> Hammond PS, Hall AJ, Prime JH (1994) The diet of grey seals around Orkney and other island and mainland sites in north-eastern Scotland. J Appl Ecol 31:340-350

Hammond PS, Berggren P, Benke H, Borchers DL and others (2002) Abundance of harbour porpoise and other cetaceans in the North Sea and adjacent waters. J Appl Ecol 39:361-376

Härkönen TJ (1987) Influence of feeding on haul-out patterns and sizes of sub-populations in harbour seals. Neth J Sea Res 21:331-339

Hastie GD, Barton TR, Grellier K, Hammond PS, Swift RJ, Thompson PM, Wilson B (2003) Distribution of small cetaceans within a candidate Special Area of Conservation; implications for management. J Cetacean Res Manag 5: 261-266

> Hooker SK, Gerber LR (2004) Marine reserves as a tool for ecosystem-based management: the potential importance of megafauna. Bioscience 54:27-39

Hoyt E (2005) Marine protected areas for whales, dolphins and porpoises. Earthscan, London

> Ingram SN, Rogan E (2002) Identifying critical areas and habitat preferences of bottlenose dolphins Tursiops truncatus. Mar Ecol Prog Ser 244:247-255

Jepson PD, Baker JR (1998) Bottlenosed dolphins (Tursiops truncatus) as a possible cause of acute traumatic injuries in porpoises (Phocoena phocoena). Vet Rec 143:614-615

Lea MA, Dubroca L (2003) Fine-scale linkages between the diving behaviour of Antarctic fur seals and oceanographic features in the southern Indian Ocean. ICES J Mar Sci 60:990-1002

Leaper R, Gillespie D, Papastavrou V (2000) Results of passive acoustic surveys for odontocetes from the British Antarctic
Survey research vessel James Clark Ross in the Southern Ocean. J Cetacean Res Manag 2:187-196

Lewis T, Gillespie D, Gordon J, Chappell O (2000) Acoustic cetacean monitoring 1996 to 1999: towards the development of an automated system. Rep No. C10563, Shell UK, Birmingham

Matthiopoulos J, McConnell BJ, Duck CD, Fedak M (2004) Using satellite telemetry and aerial counts to estimate space use by grey seals around the British Isles. J Appl Ecol 41:476-491

McConnell BJ, Fedak MA, Lovell P, Hammond PS (1999) Movements and foraging areas of grey seals in the North Sea. J Appl Ecol 36:573-590

Northridge SP, Tasker ML, Webb A, Williams JM (1995) Distribution and relative abundance of harbour porpoises (Phocoena phocoena), white-beaked dolphins (Lagenorhynchus albirostris) and minke whales (Balaenoptera acutorostrata) around the British Isles. ICES J Mar Sci 52: 55-66

Quinn GP, Keough MJ (2002) Experimental design and data analysis for biologists. Cambridge University Press, Cambridge

R Development Core Team (2003) R: A language and environment for statistical computing. R Foundation for Statistical Computing, Vienna. Available at: www.R-project.org

> Redfern JV, Ferguson MC, Becker EA, Hyrenbach KD and others (2006) Techniques for cetacean-habitat modeling. Mar Ecol Prog Ser 310:271-295

Redfern JV, Barlow J, Ballance LT, Gerrodette T, Becker EA (2008) Absence of scale dependence in dolphin-habitat models for the eastern tropical Pacific Ocean. Mar Ecol Prog Ser 363:1-14

> Robinson KP, Tetley MJ (2007) Behavioural observations of foraging minke whales (Balaenoptera acutorostrata) in the outer Moray Firth, north-east Scotland. J Mar Biol Assoc UK 87:85-86

> Ross HM, Wilson B (1996) Violent interactions between bottlenose dolphins and harbour porpoises. Proc R Soc Lond B Biol Sci 263:283-286

> Roughgarden J (1976) Resource partitioning among competing species: a coevolutionary approach. Theor Popul Biol 9:388-424

Thompson PM, McConnell BJ, Tollit DJ, MacKay A, Hunter C, Racey PA (1996) Comparative distribution, movements and diet of harbour and grey seals from the Moray Firth, N.E. Scotland. J Appl Ecol 33:1572-1584

- Thompson P, White S, Dickson E (2004) Co-variation in the probabilities of sighting harbour porpoises and bottlenose dolphins. Mar Mamm Sci 20:322-328

Tollit DJ, Black AD, Thompson PM, Mackay A and others (1998) Variations in harbour seal Phoca vitulina diet and dive-depths in relation to foraging habitat. J Zool (Lond) 244:209-222

Weir CR, Pollock C, Cronin C, Taylor S (2001) Cetaceans of the Atlantic Frontier, north and west of Scotland. Cont Shelf Res 21:1047-1071

Wiens JA (1989) Spatial scaling in ecology. Funct Ecol 3:385-397

Wilson B, Thompson PM, Hammond PS (1997) Habitat use by bottlenose dolphins: seasonal distribution and stratified movement patterns in the Moray Firth, Scotland. J Appl Ecol 34:1365-1374

Wilson B, Reid RJ, Grellier K, Thompson PM, Hammond PS (2004) Considering the temporal when managing the spatial: a population range expansion impacts protected areas based management for bottlenose dolphins. Anim Conserv 7:331-338

- Wright PJ, Jensen H, Tuck I (2000) The influence of sediment type on the distribution of the lesser sandeel, Ammodytes marinus. J Sea Res 44:243-256 